\title{
The march in place activity - a view from the local concentration of red blood cells $(C R B C)$ in the human foot dorsum
}

\author{
A atividade de marcar passo - uma abordagem à concentração das células vermelhas do \\ sangue (CCVS) da região dorsal do pé humano \\ Margarida Florindo ${ }^{1,2}$, Luís Monteiro Rodrigues ${ }^{2}$ \\ ${ }^{1}$ Department of Physiotherapy, Portuguese Red Cross Superior Health School, ESSCVP Lisboa, Portugal \\ ${ }^{2}$ CBIOS - Universidade Lusófona's Research Center for Biosciences and Health Technologies, Lisboa, Portugal \\ E-mail: mflorindo@esscvp.eu
}

\begin{abstract}
Sedentary habits are in the origin of microcirculation dysfunctions however simple tasks might act as active preventers. This study aims to evaluate potential changes in microcirculation by using subsurface polarisation light spectroscopy in human foot, while march in place. Eleven healthy volunteers (25.6 \pm 5.4 years) of both sexes, normal ankle-brachial index $(1.08 \pm 0.15)$ participated in this study. The protocol consists of one minute in standing position (Phase 1); one minute of march in place (Phase 2), and one minute of recovery (Phase 3). The local CRBC was assessed by the Tissue Viability Imaging® System probe, detecting changes between Phase 1 and Phase $2(\mathrm{p}=0.016)$ but not for Phase $3(\mathrm{p}=0.113)$. Photoplethysmography (PPG) was also used, revealing significant changes in Phase 3 both for wave amplitude $(p=0.016)$ and pulse rate $(p=0.005)$. These findings can be explained as a physiological response to movement. Gender differences were found in Phases 2 and 3 ( $p=0.011$ and $\mathrm{p}=0.006$ ), with higher CRBC values in men. Simultaneously the gastrocnemius was evaluated using surface electromyography (sEMG) with significant increases observed in Phase $2(\mathrm{p}=0.003)$. Nevertheless, additional studies are needed to understand the behaviour of the microcirculation during physical activity.
\end{abstract}

Keywords: March in place; Microcirculation; TiVi; lower limb; muscular activation

\section{Resumo}

Os hábitos sedentários estão na origem das disfunções da microcirculação, embora tarefas simples possam atuar ativamente na prevenção. Este estudo tem como objetivo avaliar alterações na microcirculação utilizando espectroscopia de luz de polarização subsuperficial na região dorsal do pé, durante a atividade de marcar passo. Onze voluntários saudáveis $(25,6 \pm 5,4$ anos $)$ de ambos os géneros com índice tornozelo-braquial normal $(1,08 \pm 0,15)$ participaram neste estudo. O protocolo consistiu: um minuto em pé (fase 1); um minuto a marcar passo (fase 2) e um minuto de recuperação (fase 3). A CCVS foi avaliada com sonda Tissue Viability Imaging ${ }^{\circledR}$ System com resultados diferentes entre a fase 1 e a fase $2(p=0.016)$ e sem alterações na fase $3(p=0.113)$. A Fotopletismografia (FPG) revelou alterações quer na amplitude de onda $(\mathrm{p}=0.016)$ quer na frequência de pulso $(\mathrm{p}=0.005)$ na fase 3 . Esses resultados podem ser explicados como uma resposta fisiológica ao movimento. Diferenças entre género foram encontradas nas fases 2 e $3(p=0,011$ e $p=0,006)$, com maiores valores de CCVS nos homens. Simultaneamente, $o$ gastrocnémio foi avaliado por eletromiografia de superfície ( $\mathrm{sEMG}$ ) com aumento significativo na fase $2(\mathrm{p}=0,003)$. No entanto, mais estudos são necessários para entender o comportamento da microcirculação durante a atividade.

Palavras-chave: Marcar passo; Microcirculação; TiVi; membro inferiore; atividade 


\section{Introduction}

The idea of a healthy peripheral circulation is generally associated with an active life, prone to regular movement. Inactivity and sedentary habits promote metabolic adaptations and microcirculatory impairments that might determine cerebrovascular disease. In healthy young adults, variations in local blood flow happen immediately with the first muscle contraction [1]. This fast and transient period is not only due to muscle activity, but also to the local vasodilator response from feedforward regulation $[2,3]$.

An adequate peripheral circulation is essential for proper tissue nutrition and is surely essential to preserve the normal function. The main force driving lower limb peripheral circulation is the activity of the leg posterior muscles that alters the pressure in the deeper vessels [4]. For their location, these vessels are more exposed to these pressures generated by the muscle. This hemodynamic phenomenon is not clearly defined but it is known that, besides the compression exerted by the muscle, the pressure gradient generates a bidirectional transmission that occurs with the perforating veins of the leg and influences the recurrent reflux [5]. It is at the microcirculatory level that the interchanges between the interstitial spaces and the vascular structures occurs, assigning a fundamental role on the peripheral activities [6-7]. Peripheral hemodynamics are not only influenced by the arteriolar branches embedded in the skeletal muscle, but also by the local endothelium controlling perfusion [8].

In cerebrovascular patients, an abnormal muscle activity and coordination are typically found, e.g., the early plantar flexor activity during stance or the early termination of tibialis anterior activity during swing [9]. The importance of these muscles to the normal peripheral perfusion might influence and even improve the overall function [10]. Inappropriate levels of activation and weakness are rarely associated with the influence of microcirculatory dysfunction in patients with central nervous system injury.

The impact of the calf muscle contraction in the lower limb circulation is known, however, there are only a few studies evaluating these variations in the dorsal region of the foot, where anatomically there are only small muscular and tendinous fibres with a very particular vascular organization. In the foot's dorsum skin, most of the blood flow goes through the deeper cutaneous vascular structures [7]. The present study evaluates the potential impact of march in place, a simple task also regarded as a preventive exercise, over the foot microcirculatory changes in the standing position.

\section{Introdução}

A ideia de uma circulação periférica saudável é geralmente associada a uma vida ativa e predisposta ao movimento. A inatividade e os hábitos sedentários induzem a disfunção metabólica e da microcirculação, conhecidos como os principais determinantes da doença cerebrovascular. Em adultos jovens saudáveis, as variações no fluxo sanguíneo local ocorrem imediatamente com a primeira contração muscular [1]. Este período rápido e transitório não se deve apenas à atividade muscular, mas também à resposta vasodilatadora local traduzido como uma regulação de feedforward $[2,3]$.

Uma circulação periférica adequada é essencial para uma adequada nutrição e oxigenação tecidual, sendo vital para a preservação da função normal. A principal força que impulsiona a circulação periférica dos membros inferiores é a atividade dos músculos posteriores da perna, que altera a pressão exercida nos vasos locais [4]. Devido à sua localização, os vasos estão mais expostos às pressões geradas pelo músculo. Esse fenômeno hemodinâmico não está claramente definido, mas sabe-se que, além da compressão exercida pelo músculo, o gradiente de pressão gera uma transmissão bidirecional que ocorre com as veias perfurantes da perna e influencia o refluxo recorrente [5]. É no nível microcirculatório que ocorrem as trocas entre os espaços intersticiais e as estruturas vasculares, atribuindo um papel fundamental da microcirculação a todas as atividades que ocorrem na periferia [6-7]. É importante considerar que a hemodinâmica periférica não é apenas influenciada pelos ramos arteriolares embutidos no músculo esquelético, mas também pelo endotélio local que controla o fluxo sanguíneo [8].

Nos pacientes cerebrovasculares, a atividade muscular e a coordenação de movimento encontra-se alterada, como é exemplo a diminuição da atividade dos flexores plantares durante a postura e movimento ou um término precoce da atividade tibial anterior durante o swing [9]. A importância do funcionamento dos músculos da perna pode determinar uma perfusão normal à periferia, e melhorar a função global do membro inferior [10]. Nível inadequado de ativação e fraqueza musculares raramente são associados à influência da disfunção microcirculatória em pacientes com lesão do sistema nervoso central.

O impacto da contração muscular da região posterior da perna e nomeadamente dos músculos gastrocnémios na circulação dos membros inferiores é conhecido, mas existem poucos estudos que avaliam as variações na região dorsal do pé, onde anatomicamente existem apenas pequenas fibras musculares e tendinosas com uma 


\section{Materials and Methods}

Eleven young healthy volunteers $(25.6 \pm 5.4$ years $)$ both sexes (six female and five male) with normal ankle-brachial index $(1.08 \pm 0.15)$ were selected upon informed written consent. The body weight was measured using a bio-impedance balance Tanita BC-730 (Tanita Corporation, Japan) and the stature measured with a Seca Wall Tester 206 (Germany). Body mass index (BMI) was calculated as weight $(\mathrm{kg}) /$ height $^{2}(\mathrm{~m})$ being 21.2 \pm 2.40 for female and $24.2 \pm 2.31$ for male volunteers. All participants declared a moderately active lifestyle. All procedures followed the Helsinki Declaration [11]. Experiments took place in the same room with a constant ambient temperature $\left(25^{\circ} \mathrm{C} \pm 1\right)$. after 10 minutes adaptation to room condition, the baseline assessment was registered in the standing position. Then, volunteers performed a three minute protocol divided into three phases - 1 minute in a quiet stationay position (Phase 1); 1 minute of march in place (Phase 2) and, finally 1 minute of recovery in the resting position as in phase 1 (Phase 3).

The TiVi system (Tissue Viability Imaging ${ }^{\circledR}$ TiVi8000, WheelsBridge, Sweden) was used to measure changes in the local concentration of red blood cells (CRBC) in the skin. The system provides information about microcirculation by using subsurface polarisation green light spectroscopy [12]. A portable probe was placed in the anterointernal region of the left foot, one centimetre above the metatarsophalangeal joint, leaving the ankle joint free to perform the movement. The red blood cells absorb light superficially in green wave-length region while the surrounding tissue of the dermis absorbs lesser light, which can be identified by separating the images in different planes (green, blue and red colours) [13]. Based on this principle, the chosen region of interest (ROI) for quantification purposes were those regions with a higher concentration of red blood cells (Figure 1). A mean TiVi index was calculated from the same area of skin in each subsequent image, giving the change in the mean local of CRBC over the three phases.

A Photoplethysmography (PPG) reflection sensor (Blood Volume Pulse Sensor, PLUX Biosignals, Portugal) was used in the equivalent site at the contralateral foot. PPG detects blood volume changes in the capillary bed, generating a pulsatile wave in cardiac synchrony, allowing the identification of the Pulse Rate (PR) and variations in the amount of local blood perfusion [14]. To minimize the occurrence of probe-tissue movement artefacts, a double-sided adhesive strip was used to hold the probe adhering to the skin [15]. The influence organização vascular muito particular. Nesta região do pé a maior parte do fluxo sanguíneo passa nas estruturas vasculares cutâneas mais profundas [7]. O presente estudo pretende avaliar o potencial impacto da atividade de marcar passo, pois é uma tarefa simples e também considerada como um exercício preventivo, sobre as alterações da microcirculação no pé durante a posição de pé.

\section{Materiais e Métodos}

Onze jovens voluntários saudáveis $(25,6 \pm 5,4$ anos $)$, de ambos os sexos (seis mulheres e cinco homens) com índice tornozelo-braço normal $(1,08 \pm 0,15)$ foram selecionados mediante consentimento informado por escrito. $\mathrm{O}$ peso corporal foi medido utilizando uma balança de bioimpedância Tanita BC-730 (Tanita Corporation, Japão) e a estatura medida com um Seca Wall Tester 206 (Alemanha). O índice de massa corporal (IMC) foi calculado como peso $(\mathrm{kg}) /$ altura2 (m), e estabelecida uma média para comparação entre géneros. $\mathrm{O}$ género feminino apresentou valores de IMC de $21,2 \pm 2,40$ e o género masculino de 24,2 $\pm 2,31$.

Todos os participantes declararam um estilo de vida moderadamente ativo. Todos os procedimentos seguiram a Declaração de Helsinki [11]. As experiências ocorreram na mesma sala com uma temperatura ambiente constante $\left(25^{\circ} \mathrm{C} \pm 1\right)$. após 10 minutos de adaptação à condição ambiental, a avaliação de referência foi registrada na posição de pé. Em seguida, os voluntários realizaram um protocolo de três minutos, dividido em três fases: 1 minuto em posição de pé parada (fase 1); 1 minuto de atividade de marcar passo (fase 2) e, finalmente, 1 minuto de recuperação em posição sobreponível à fase 1 (fase 3 ).

A sonda Tissue Viability Imaging ${ }^{\circledR}$ System (TiVi) (TiVi8000, WheelsBridge, Suécia) foi usada para medir mudanças na concentração local de células vermelhas do sangue (CCVS) na pele. Este sistema fornece informações sobre a microcirculação usando espectroscopia de luz verde de polarização subsuperficial [12]. Neste estudo, uma sonda TiVi foi colocada na região antero-interna do pé esquerdo, um centímetro acima da articulação metatarso-falângica, deixando a articulação do tornozelo livre para realizar o movimento. As células vermelhas do sangue absorvem a luz superficialmente na região do comprimento de onda verde, enquanto o tecido circundante da derme absorve menos luz, o que pode ser identificado pela separação das imagens em diferentes planos (cores verde, azul e vermelha) [13]. Com base nesse princípio, a escolha da região de in- 
of ambient light on PPG was minimal because the room was dark during data collection.

The surface electromyography (sEMG) data was acquired in the gastrocnemius with two $10 \mathrm{~mm}$ diameter active electrodes placed in the calf region of the right limb with a distance of $20 \mathrm{~mm}$ between them, following the direction of the muscular fibres to ensure the maximal sEMG amplitude. One reference electrode was placed on the inner malleolus [16-17]. The amplitude of sEMG signal in each phase was expressed as a root mean square (rms). PPG sensor and sEMG electrodes were attached to a microprocessor board (BITalino Plugged board, PLUX Biosignals, Portugal). The PPG signal was calculated as the number of waveforms per minute (/min). Blood perfusion, sEMG signal, and PR means were calculated in each phase.

Data analysis involved a customized program written in MatLab (Mathworks Inc., USA). The Wilcoxon signedrank test was used for phase comparisons, and a $\mathrm{p}<0.05$ value adopted. teresse (ROI) para fins de quantificação foi a região onde se verificava uma maior concentração de células vermelhas do sangue (Figura 1). Um índice médio de TiVi foi calculado a partir da mesma área da pele em cada imagem subsequente, para verificar as alterações médias locais de CCVS ao longo das três fases. Um sensor de reflexão de fotopletismografia (Sensor de Impulso de Volume de Sangue, PLUX Biosignals, Portugal) foi utilizado exatamente no mesmo local da sonda TiVi, mas no pé contralateral. A FPG é uma técnica simples e prática que apresenta uma onda pulsátil aparecendo em sincronia cardíaca, o que permite a identificação da frequência de pulso (FP) [14]. Para minimizar a ocorrência de artefactos de movimento do tecido cutâneo na sonda, uma fita adesiva de dupla face foi usada para manter a sonda bem aderente à pele [15]. A influência da luz ambiente no FPG foi mínima porque a sala esteve escura durante a recolha de dados.

Os dados da eletromiografia de superfície (sEMG) foram adquiridos no músculo gastrocnémio com dois

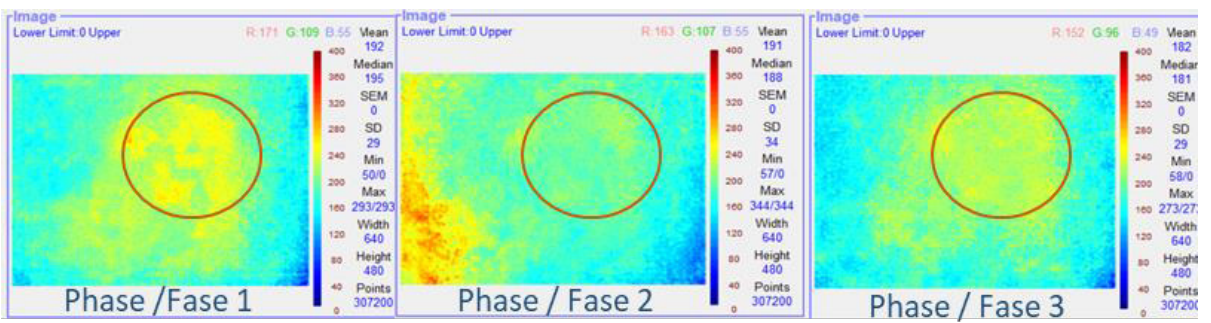

Figure 1/ Figura 1 - Example of the region of interest (ROI) to evaluate the $\mathrm{CRBC}$ during the 3 phases of the protocol/ Exemplo da região de interesse (ROI) para a avaliação da CCVS durante as 3 fases do protocolo

\section{Results and Discussion}

A mean TiVi index was obtained from each image, in each phase. In Phase 2 CRBC significantly decreased $(p=0.016)$ when compared to Phase 1 (Table 1). This result is in line with previous studies regarding the foot microcirculation using PPG, suggesting that the calf muscle activity in the standing position decreases the blood perfusion at the foot region [15]. Other studies indicate that this response is due to the venoarterial reflex (or oedema protection reflex) that reacts to the vasodilator response starting in the upright position [18]. In the presence of the initiated activity, the variations between the loading moments and the elevation of the foot from the floor, mechanisms are required that maintain stability of the blood volume, not allowing, on the one hand, that the volume increases too much in the extremity of the lower limb while, on the other, guaranteeing the flow needed for the muscular activity elétrodos ativos de $10 \mathrm{~mm}$ de diâmetro colocados na região do ventre muscular da região posterior da perna direita com uma distância de $20 \mathrm{~mm}$ entre eles, seguindo a direção das fibras musculares para garantir a máxima amplitude de sEMG. Um elétrodo de referência foi colocado no maléolo interno [16-17]. A amplitude do sinal de EMGs em cada fase foi expressa como uma raiz quadrada média (root mean square - rms). Tanto o sensor FPG como os elétrodos sEMG foram acoplados a uma placa de microprocessador (placa BITalino Plugged, PLUX Biosignals, Portugal). O sinal de FPG foi calculado como o número de formas de onda por minuto (/ min). O fluxo sanguíneo, o sinal de EMGs e os meios FR foram calculados em cada fase.

Todos os dados foram analisados utilizando um programa customizado escrito em MatLab (Mathworks Inc., EUA). O teste dos postos sinalizados de Wilcoxon foi utilizado para as comparações de fases e adotou-se um valor de $\mathrm{p}<0.05$. 
[19-20]. As shown in Phase 3 (Table 1) this flow is rapidly controlled with a fast return to normal values within the duration of this phase $(\mathrm{p}=0.113)$. In the standing position, the absence of regulatory mechanisms would permit the vessels of the foot to fill with between 300 and $800 \mathrm{ml}$ of blood corresponding to the gravitational displacement of blood, thus, in healthy subjects, this is a preventive phenomenon [20].

It was not possible to read PPG during Phase 2, as the impact of the foot on the floor created many artefacts. However, we were able to correlate PPG (AU) and Pulse Rate between Phase 1 and Phase 3 (Table 1) and we observed significant differences between Phases 1 and 3 for the PPG values $(\mathrm{p}=0.016)$ and for the pulse rate $(\mathrm{p}=0.005)$ (Table 1$)$. This increase was observed in all subjects, with the exception ofone that maintained the same PR throughout. When we investigated the reasons for this variation, we only found cognitive factors related to attention, since all subjects were very attentive during the protocol and especially in the changes between phases [21-22]. A rapid and transient increase in blood flow peaks, within approximately five cardiac cycles, was previously reported in young healthy humans during aerobic exercise [3], explaining the differences found in the PPG waveform amplitude.

The gastrocnemius sEMG results show a significant increase during Phase $2(\mathrm{p}=0.003)$, suggesting an active contribution during the gait cycle related to the gradual and alternating recruitment of motor units. However, when comparing Phase 3 (recovery) with baseline (Phase 1), we found that muscle activity is still significantly elevated $(p=0.010)$, likely due to the maintenance of a higher physiologic postural tone. The gastrocnemius muscle is considered one of the most important muscles in functional control and stabilization of the standing position with reference to a set of natural base and differential oscillation signal patterns, identified as key determinants in muscle rest [23]. We found two studies that address muscle stiffness and tone after exercise, and in one study, differences were recorded iwithin 5 minutes after the end of exercise [24]. In the second study, different results were found for two groups that performed different exercises. They found an increase in muscle stiffness after training (intensive exercise) for one group while in the second group (isometric training), there was no difference from baseline values after exercise [25]. More studies are needed to look at whether residual tonus remains immediately after a muscle activity ends.

The CBRC changes between sexes revealed significant differences in the Phases 2 and $3(p=0.011$ and $\mathrm{p}=0.006$ ) with higher values for men (Table 1$)$. In an

\section{Resultados e Discussão}

Um índice médio de TiVi foi obtido de cada imagem, em cada fase. Na fase 2, os CCVS diminuíram significativamente $(\mathrm{p}=0,016)$ quando comparados à fase 1 (tabela 1). Este resultado está de acordo com estudos anteriores sobre a microcirculação do pé utilizando FPG, sugerindo que a atividade muscular da região posterior da perna na posição em pé, diminui a perfusão sanguínea na região do pé [15]. Outros estudos indicam que essa resposta é devida ao reflexo venoarterial (ou reflexo de proteção do edema) que reage à resposta vasodilatadora a partir da posição ereta [18]. Na presença da atividade iniciada, as variações entre os momentos de carga e a ausência do pé do chão, requer mecanismos que mantenham a estabilidade do volume sanguíneo, não permitindo, por um lado, que o volume aumente demais na extremidade do membro inferior, garantindo no entanto o fluxo necessário à atividade muscular [1920]. Como se verifica na fase 3 (tabela 1) este fluxo é rapidamente controlado com um retorno rápido aos valores normais dentro da duração desta fase $(p=0,113)$. Na posição em pé, a ausência de mecanismos reguladores permitiria o preenchimento dos vasos dos pés entre 300 e $800 \mathrm{ml}$, correspondendo ao deslocamento gravitacional do sangue, de modo que, em indivíduos saudáveis, esse é um fenômeno preventivo [20].

Não foi possível ler o FPG durante a fase 2, já que o impacto do pé no chão causou muitos artefactos. No entanto, conseguimos correlacionar a FPG (UA) e a Frequência de Pulso entre a Fase 1 e a Fase 3 (Tabela 1) onde observámos diferenças significativas quer paraos valores de FPG $(p=0,016)$ quer para a Frequência de Pulso $(p=0,005)$ (tabela 1). Esse aumento foi observado em todos os sujeitos, com exceção de um que manteve o PR sempre com os mesmos valores. Quando investigamos os motivos dessa variação, encontramos apenas fatores cognitivos relacionados à atenção, uma vez que todos os sujeitos estavam muito atentos durante o protocolo e, principalmente, nas mudanças entre as fases [21-22]. Para explicar as diferenças encontradas na amplitude da onda FPG na fase 3, encontrámos um estudo que relatou um aumento rápido e transitório dos picos de fluxo sanguíneo, em aproximadamente cinco ciclos cardíacos, em humanos jovens e saudáveis durante o exercício aeróbico [3].

Os resultados do sEMG dos gastrocnémios apresentaram um aumento significativo durante a fase 2 $(p=0.003)$, sugerindo a sua contribuição durante o ciclo da marcha, relacionado com o recrutamento gradual e alternado de unidades motoras. No entanto, ao comparar a fase 3 (recuperação) com o início (fase 1), 
investigation comparing blood red cell passage values in the upper limb antecubital region, the authors identified higher values for men compared with women [26]. However, other studies on microcirculation did not find differences between genders [27], so further studies seem to be necessary to compare responses among healthy individuals with different physiological characteristics. verificamos que a atividade muscular ainda é significativamente elevada $(\mathrm{p}=0.010)$, provavelmente devido à manutenção de um tónus postural fisiológico elevado. O músculo gastrocnémio é considerado um dos músculos mais importantes no controle funcional e estabilização da posição em pé, com referência a padrões de sinal de base natural e oscilação diferencial determinantes, mesmo durante o repouso muscular [23]. Encontrámos dois estudos que abordam a rigidez muscular e o tónus

Table 1/ Tabela 1 - Results (mean \pm standard deviation) of variables for each phase of the protocol. F - Female; M - Male; N/A - Not Applicable; Statistical comparison for resting phase. * - statistically significant $(\mathrm{p}<0.05) /$ Resultados (média \pm desvio-padrão) de cada variável de cada fase do protocolo. F - Feminino; M - Masculino; NA - Não Aplicável; Comparação estatística para a fase de repouso. * -estatisticamente significativo $(\mathrm{p}<0.05)$.

\begin{tabular}{|c|c|c|c|c|c|c|c|c|c|c|}
\hline \multirow[b]{2}{*}{ Gender/Género } & & \multicolumn{3}{|c|}{ Phase 1 / Fase 1} & \multicolumn{3}{|c|}{ Phase 2 / Fase 2} & \multicolumn{3}{|c|}{ Phase 3 /Fase 3} \\
\hline & & $\mathbf{F}$ & $\mathbf{M}$ & Total & $\mathbf{F}$ & M & Total & $\mathbf{F}$ & M & Total \\
\hline \multirow{3}{*}{$\begin{array}{l}\text { CRBC (AU) } \\
\text { CCVS (UA) }\end{array}$} & mean/média & 252.9 & 323.3 & 284.9 & 228.9 & 309.0 & 265.3 & 233.5 & 327.1 & 276.0 \\
\hline & Sd/dp & 23.3 & 70.9 & 60.2 & 15.8 & 49.2 & 55.8 & 16.3 & 55.8 & 61.3 \\
\hline & $\mathbf{p}$ & \multicolumn{2}{|c|}{0.144} & - & \multicolumn{2}{|c|}{$0.011 *$} & $0.016^{*}$ & \multicolumn{2}{|c|}{$0.006^{*}$} & 0.113 \\
\hline \multirow{3}{*}{$\begin{array}{c}\text { sEMG (rms) } \\
\text { racio }\end{array}$} & mean/média & 0 & 0 & 0 & 0.9 & 1.1 & 0.98 & 0.1 & 0.07 & 0.09 \\
\hline & Sd/dp & 0 & 0 & 0 & 0.5 & 1.5 & 1.0 & 0.2 & 0.1 & 0.1 \\
\hline & $\mathbf{p}$ & \multicolumn{3}{|c|}{1} & \multicolumn{2}{|c|}{0.855} & $0.003 *$ & \multicolumn{2}{|c|}{0.929} & $0.01 *$ \\
\hline $\mathrm{PR} / \mathrm{FP}$ & mean/média & 73.5 & 62.2 & 63 & & & & 75.7 & 66.8 & 71.6 \\
\hline
\end{tabular}

\section{Conclusion}

The TiVi technique allows to identify the concentration of red blood cells over a period of time in which the subject performs one or more tasks. In our experimental conditions, we were able to identify microcirculation changes caused by the march in place activity and probably sex related. More studies are needed to understand the behaviour of the microcirculation during activity, however the assessment of the movement CBRC may be indicative of the circulatory dynamics within the feet in relation to movement.

\section{Acknowledgements}

The authors would like to express their thanks to all the volunteers for their participation in this study. This após o exercício e, num dos estudos as diferenças foram registradas em 5 minutos após o término do exercício [24]. No segundo estudo, foram encontrados diferentes resultados para dois grupos que realizaram diferentes exercícios, com um aumento na rigidez muscular após o treino (exercício intensivo) para um grupo, enquanto no segundo grupo (treino isométrico), não houve diferenças para os valores basais [25]. Mais estudos são necessários para verificar se o tónus residual permanece imediatamente após o término da atividade muscular.

As mudanças na CCVS entre géneros revelaram diferenças significativas nas fases 2 e $3(p=0.011$ e $\mathrm{p}=0.006$ ), com maiores valores para os homens (tabela 1). Numa investigação realizada em 2018 para comparar os valores de passagem de células vermelhas do sangue na região cubital anterior do membro superior, os autores verificaram haver um aumento no grupo de homens em comparação com dois grupos de mulheres 
work was supported by national funds from FCT, within the project UID/DTP/04567/2016

\section{Conflict of interest}

The authors declare that there is no financial or personal relationship that might be perceived as posing a potential conflict of interest
[26]. No entanto, outros estudos sobre a microcirculação não encontraram diferenças entre os gêneros [27], portanto, estudos adicionais parecem ser necessários para comparar as respostas entre indivíduos saudáveis com diferentes características fisiológicas.

\section{Conclusão}

A técnica de TiVi permite identificar a concentração de glóbulos vermelhos no sangue durante um período de tempo em que o indivíduo realiza uma ou mais tarefas. Em nossas condições experimentais, fomos capazes de identificar alterações na microcirculação causadas pela atividade do passo de marcação e provavelmente relacionadas ao sexo. Mais estudos são necessários para compreender o comportamento da microcirculação durante a atividade e reconhecemos que a avaliação do movimento da CCVS pode ser indicativa da dinâmica circulatória, nos pés em relação ao movimento.

\section{Agradecimentos}

Os autores gostariam de agradecer a todos os voluntários pela participação neste estudo. Este trabalho foi financiado por fundos nacionais da FCT, dentro do projeto UID/DTP/04567/2016

\section{Conflito de Interesses}

Os autores declaram não existir qualquer relação pessoal ou financeira que possa ser entendida como representando um potencial conflito de interesses. 


\section{References /Referências}

[1] Sinkler SY, Segal SS. Rapid versus slow ascending vasodilatation: intercellular conduction versus flow-mediated signalling with tetanic versus rhythmic muscle contractions. J Physiol 595.23 (2017) pp 7149-7165. DOI: 10.1113/JP275186

[2] Hearon CM, Dinenno FA. Regulation of skeletal muscle blood flow during exercise in ageing humans. J Physiol 594.8 (2016) pp 2261-2273. DOI: $10.1113 / \mathrm{JP2} 20593$

[3] Tschakovsky ME, Matusiak K, Vipond C, McVicar L. Lower limb-localized vascular phenomena explain initial orthostatic hypotension up on standing from squat. Am J Physiol Heart Circ Physiol. 2011 Nov; 301(5):H2102-12. doi: 10.1152/ajpheart.00571.2011.

[4] Silva H, Ferreira H, Bujan J, Monteiro Rodrigues L. Comparing passive leg raising and suprasystolic ankle occlusion responses to quantify age-related microcirculatory status. Biomed Biopharm Res. 2015; (12) 2: , 215-222.

[5] Recek C. Calf pump activity influencing venous hemodynamics in the lower extremity. Int J Angiol. 2013 Mar;22(1):23-30.

[6] Costello JT, McNamara PM, O'Connell ML, Algar LA, Leahy MJ, Donnelly AE. Tissue viability imaging of skin microcirculation following exposure to whole body cryotherapy $\left(-110^{\circ} \mathrm{C}\right)$ and cold water immersion $\left(8^{\circ} \mathrm{C}\right)$. 2014. Arch Exerc Health Dis 4 (1): 243-250. DOI: 10.5628/aehd.v4i1.152

[7] Tulevski II, Ubbink DT, Jacobs MJ. Red and Green Laser Doppler Compared with Capillary Microscopy to Assess Skin Microcirculation in the Feet of Healthy Subjects Microvascular Research. 58, 83-88 (1999) Article ID mvre.1999.2159, available online at http://www.idealibrary.com

[8] Kwang-Seok H, Kijeong K. Skeletal muscle contraction-induced vasodilation in the microcirculation. Journal of Exercise Rehabilitation 2017;13(5):502507. https://doi.org/10.12965/jer.1735114.557

[9] Goltsov A, Anisimova AV, Zakharkina M, Krupatkin AI, Sidorov VV, Sokolovski SG and Rafailov E (2017) Bifurcation in Blood Oscillatory Rhythms for Patients with Ischemic Stroke: A Small Scale Clinical Trial using Laser Doppler Flowmetry and Computational Modeling of Vasomotion. Front. Physiol. 8:160. doi: 10.3389/fphys.2017.00160

[10] Srivastava S, Patten C, Kautz SA. Altered muscle activation patterns (AMAP): an analytical tool to compare muscle activity patterns of hemiparetic gait with a normative profile. Journal of NeuroEngineering and Rehabilitation (2019) 16:21 https://doi.org/10.1186/s12984-019-0487-y

[11] World Medical Association Declaration of Helsinki Ethical Principles for Medical Research Involving Human Subjects. JAMA. 2013; 310(20):21912194

[12] Nilsson G, Zhai H, Chan H, Farahmand S, Maibach HI. Cutaneous bioengineering instrumentation standardization: the Tissue Viability Imager. Skin Research and Technology 2009; 15: 6-13. DOI: 10.1111/j.1600-0846.2008.00330.x

[13] Henricson J, Nilsson A, Tesselaar E, Nilsson G, Sjöberg F. Tissue viability imaging: Microvascular response to vasoactive drugs induced by iontophoresis. Microvascular Research 78 (2009) 199-205. doi:10.1016/j.mvr.2009.04.008.

[14] Allen J. Photoplethysmogrphy and it application in clinical physiological measurement. Physiological Measurement. Mar;28(3):R1-39. Epub 2007 Feb 20.

[15] Florindo M, Silva H, Monteiro Rodrigues. Impact of the isometric contraction of the calf on the local microcirculation Biomedical Sciences/Ciências Biomédicas Biomed Biopharm Res. 2017; (14) 2: 179-186. DOI: 10.19277/bbr.14.2.160

[16] Naik GR, Al-Ani A, Gobbo M and Nguyen HT (2017) Does Heel Height Cause Imbalance during Sit-to-Stand Task: Surface EMG Perspective. Front. Physiol. 8:626. doi: 10.3389/fphys.2017.00626

[17] De Luca CJ. The use of surface electromyography in biomechanics. Journal of Applied Biomechanics. 1997, 13 (2): 135-163.

[18] Klonizakis M, Yeung JMC, Lingam K, Manning G, Donnelly R. Effects of Posture and Venous Insufficiency on Endothelial-dependent and -independent Cutaneous Vasodilation in the Perimalleolar Region Eur J Vasc Endovasc Surg 26, $100 \pm 104$ (2003)

doi:10.1053/ejvs.2002.1953, available online at http://www.sciencedirect.com

[19] Caldwell J, Wardlow G, Branch P, Ramos M, Black C, Ade C. Effect of exercise-induced muscle damage on vascular function and skeletal muscle microvascular deoxygenation. Physiol Reports, 2016,4 (22), e13032.

[20] Truijen J, Kim YS, Krediet CTP, Stok WJ, Ko lgen RS, Secher NH, van Lieshout JJ. Orthostatic leg blood volume changes assessed by near-infrared spectroscopy. Exp Physiol 97.3 (2012) pp 353-361. DOI: 10.1113/expphysiol.2011.061051.

[21] Mankus AM, Aldao A, Kerns C, Mayvile EW, Mennin DS. Mindfulness and heart rate variability in individuals with high and low generalized anxiety symptoms. Behaviour Research and Therapy 51 (2013) 386e391. doi.org/10.1016/j.brat.2013.03.005

[22] Sun S, Hu C, Pan J, Liu C and Huang M (2019) Trait Mindfulness Is Associated With the Self-Similarity of Heart Rate Variability. Front. Psychol. 10:314. doi: 10.3389/fpsyg.2019.00314

[23] Schoenrock B, Zander V, Dern S, Limper U, Mulder E, Veraksitš A, Viir R, Kramer A, Stokes MJ, Salanova M, Peipsi A and Blottner D (2018) Bed Rest, Exercise Countermeasure and Reconditioning Effects on the Human Resting Muscle Tone System. Front. Physiol. 9:810. doi: 10.3389/fphys.2018.00810

[24] Sang-Wan H, Lee JW. Effects of integrated treatment with LED and microcurrent on muscle tone and stiffness in the calf muscle during moderate aerobic exercise. 2018. J. Phys. Ther. Sci. 30: 816-819.

[25] Kubo K, Ishigaki T, Ikebukuro T. Effects of plyometric and isometric training on muscle and tendon stiffness in vivo Physiol Rep, 5 (15), 2017 , e13374 https://doi.org/10.14814/phy2.13374

[26] Grau M, Cremer JM, Schmeichel S, Kunkel M and Bloch W. Comparisons of Blood Parameters, Red Blood Cell Deformability and Circulating Nitric Oxide Between Males and Females Considering Hormonal Contraception: A Longitudinal Gender Study. Front. Physiol. 2018. 9:1835. doi: 10.3389/ fphys.2018.01835

[27] Monteiro-Rodrigues L, Pinto PC, Leal A. Transcutaneous flow related variables measured in vivo: the effects of gender. BMC Dermatology 2001, 1:4. http://www.biomedcentral.com/1471-5945/1/4 